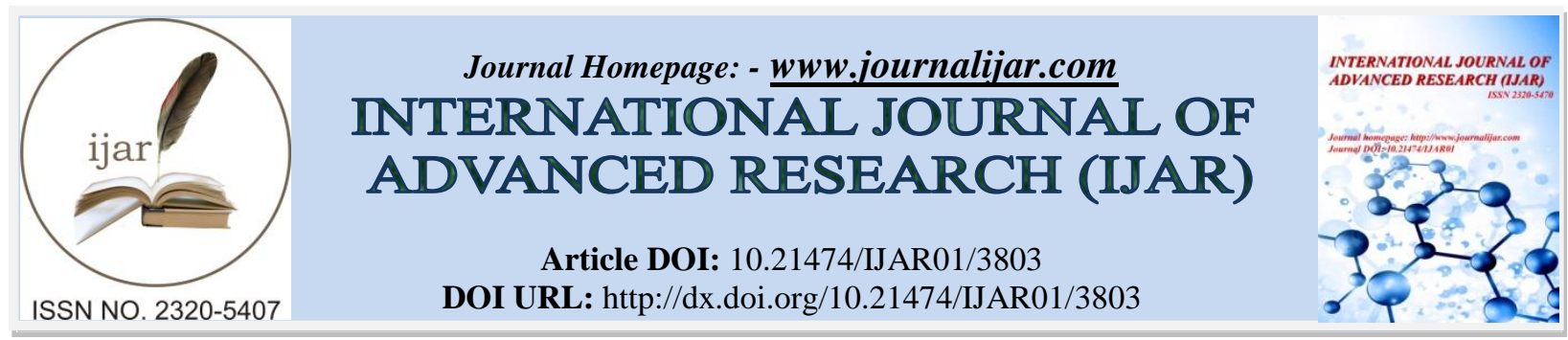

RESEARCH ARTICLE

\title{
CERTAIN WORKS DONE ON SHWITRA (VITILIGO) BY AYURVEDIC MANAGEMENT: A BRIEF REVIEW.
}

\author{
Rajdip Rao ${ }^{1 *}$, Prof. A. B.Thakar ${ }^{2}$, Prof. K. S. Patel ${ }^{3}$, Dr. N. N. Bhatt ${ }^{4}$, Dr. Rahul Gandhi ${ }^{5}$ and Shital Bhagiya ${ }^{6}$ \\ 1. PG Scholar, Department of Panchakarma, IPGT \& RA, Jamnagar, Gujarat. \\ 2. Professor and Head, Department of Panchakarma, IPGT \& RA, Jamnagar, Gujarat. \\ 3. Prof. \& I/C Director, IPGT \& RA, Jamnagar. \\ 4. Asst. Prof., Dept. of Kayachikitsa, IPGT \& RA, Jamnagar, Gujarat. \\ 5. Asst. Prof., Dept. of Panchakarma, IPGT \& RA, Jamnagar, Gujarat. \\ 6. PhD Scholar, Dept. of Panchakarma, IPGT \& RA, Jamnagar, Gujarat
}

\section{Manuscript Info}

Manuscript History

Received: 20 February 2017

Final Accepted: 11 March 2017

Published: April 2017

Key words:-

Ayurveda, Review, Shwitra, Vitiligo

\begin{abstract}
In Ayurveda, Shwitra has been listed to be the worst amongst Kustha to cause disfigurement of the body. Shwitra is considered as one of the varieties of Kushtha in the Ayurvedic Classics, caused vitiation of Tridoshas and Dhatus like Rakta, Mansa and Meda. Based on Symptoms, Shwitra can be correlated with Vitiligo. Vitiligo is the problem described in the modern medicine as auto immune disease which manifest as white spot on the skin. Ayurveda has incorporated this condition into the broad heading of Shwitra. The Shwitra is the group of symptoms which manifest as the spot on the skin and causes cosmetic imbalance body which ultimately leads to many socialized psychological stigma in life of the patient. Considering the significance of therapeutics, a number of studies of different levels have been carried-out in the various PG Departments of various colleges of universities. Total ten studies were screened, which compiled the impact of classical and clinical guidelines, safety issues and therapeutic utilities in the management of Shwitra (Vitiligo).
\end{abstract}

Copy Right, IJAR, 2017,. All rights reserved.

\section{Introduction:-}

Ayurveda emphasizes on maintenance of positive health and alleviation of the diseases engulfing human kind ${ }^{[i]}$, among which skin diseases are one, which are visible and agonizing the individual psycho-somatically ${ }^{\text {[ii] }}$. With the increase awareness and global acceptance, it is a need of time to work on individual Karma with different formulation in different diseases in a scientific manner. Vitiligo is such a common chronic and progressive skin disease characterized by the lack of melanin pigments producing skin patches with sharp and often hyper pigmented edges. This disease affects approximately $1 \%$ of the world-wide population ${ }^{\text {[iii] }}$. Vitiligo is the problem described in the modern medicine as auto immune disease which manifest as white spot on the skin. Ayurveda has incorporated this condition into the broad heading of Shwitra. There are two main line of treatment chiefly described in the classics. These are Shodhana (bio-purification) and Shamana (palliative therapy) ${ }^{[i v]}$. Shodhana (Panchakarma) are unique therapies of Ayurveda, which attract the attention of the suffering people for the satisfactory treatment of various chronic, autoimmune, degenerative, hormonal and metabolic disorders on one side and on the other side, it is gaining global reorganization for its preventive and primitive aspects ${ }^{[\mathrm{v}]}$. Shodhana therapy is superior to the 
Shamana therapy as the former removes the ailment permanently. The Shodhana therapy not only cures the diseases but also makes the body more immune and so fulfils both the aims of Ayurveda ${ }^{\text {[vi] }}$. Three hypotheses are prevailing about the etiology of the disease like self-destruction theory, neurological theory and autoimmune theory. None of them is satisfactory yet most of scientist has considered Vitiligo as autoimmune. One popular theory is that melanocytes are the target of a cell-mediated autoimmune attack and why only focal areas are affected that remains unexplained $^{\text {[vii] }}$.

\section{Materials and Method:-}

Works carried-out in the various departments of various colleges of universities at PhD and PG levels during 2001 2015 were compiled and screened to provide rational of Ayurvedic therapeutics.

\section{Results and Observations:-}

Tiwari S.K. (2001) ${ }^{[\text {viii] }}$ : Under the title Evaluation of the efficacy of Dhatrayadi Yoga (Internal) and Avalgujadi lepa (external) along with and without Shodhana (Vamana) in Shwitra (with special reference to Vitiligo) is said to have efficacy in relation to regulate Shwitra i.e. Vitiligo. Out of 30 patients all satisfied with the treatment schedule and expressed normalcy both symptomatic and on patch colour index. The $\mathrm{P}$ value shows high significance as $\mathrm{P}<0.001$. The result is as follows. $60 \%$ of patients got cured and $40 \%$ have remarkable relief without showing any kind of adverse effects.

\section{Venkaraddiyavar B.H. (2006) ${ }^{[\mathrm{ix}]}$ :-}

The present study was under taken to evaluate the effect of lepa along with shamanoushadhi in the management of Shwitra. The complete cure was observed, 6.66\% i.e.2 patients, who are having small lesion and recent onset. The remaining patients were also relieved moderately, from their symptoms. Clinical and statistical analysis reveals that the systemic corrections can be done with internal preparation and the local stimulation by synthesis of melanin through external application may be effective in the management of Shwitra vis-à-vis Vitiligo.

Manisha Goyal (2008) ${ }^{[\mathrm{x}]}$ :-

Total 44 patients were registered for the clinical trial of Karpanpatru Taila. Patient having classical sign and symptoms of Shwitra were selected and randomly divided into three groups from the O.P.D. \& I.P.D. of I.P.G.T. \& R.A., Gujarat Ayurved University, Hospital, Jamnagar. Group A and B contains 15 patients in each group out of these 12 patients were completed their course while 3 patients were LAMA. In Group C 14 patients were registered. Here 12 patients were completed their course and 2 patients were LAMA. Group A- Karpanpatru Taila prepared by Gomutra, Group B- Karpanpatru Taila prepared by Kanji and Group C- Karpanpatru Taila prepared by Takra was applied externally. Karpanpatru Taila (Q.S.) applied once/day followed by exposure to sunlight for 5 minutes in the morning for 8 weeks and 4 weeks of follow up period. Karpanpatru Taila prepared with Takra (Group B) as liquid media showed better result in clinical study than other groups i.e. Group A and Group C.

Jayawardana C. T. (2009) ${ }^{[\mathrm{xi}]}$ :-

When comparing two different treatment groups i.e. Bakuchi Haritala Yoga group and Bakuchi Thailaya group with each other, the higher relief of the symptoms was obsereved in Bakuchi Haritala Yoga group. Probable mode of action of Bakuchi Haritala Yoga was proved in Ayurvedic concept of Varnotpatti (formation of colour) and Guna (properties), Karma (action) theory. A least effect on Shwitra was shown by Bakuchi Thailaya when compared to Bakuchi Haritala Yoga.

Mittalakod K.S. (2009) ${ }^{[\mathrm{xii}]}$ :-

The study was single blind prospective clinical trial and carried out by single group method. Clinical trial was conducted over 30 patients with confirmed diagnosis of Shwitra. Each patient was given 65mg of Shwitrari rasa once with honey, per day $65 \mathrm{mg}$ is increased up to 60 days and Shwitra lepa is given for external application along with Jala for 30 days with 15 days of follow up period. The complete cure was observed, $6.66 \%$ i.e 2 patients who are having small lesion and recent onset. The remaining patients were also relieved moderately; from their symptoms. The result reveals that Shwitrari rasa and lepa has got good result against Shwitra. Shwitrari rasa \& lepa has shown better zone of inhibition of Shwitra compared to modern drugs. 
Deepika Tyagi (2010) ${ }^{[\mathrm{xiii}]}$ :-

For present study 20 patients who fulfilling the clinical criteria for diagnosis of Shwitra were randomly selected and subdivided into two groups, 10 in each group. In both groups Haritakyadi Shodhana Yoga (prior to Shamana Chikitsa for Shodhana).Group A: Khadiradi Yoga (internally) 6gms thrice \& Khadiradi Taila (externally) accord to patch. Group B: Kakodumbara Vati (internally) 6gms thrice \& Kakodumbara Taila (externally) accord to patch. In both group Taila is use for external application with sun exposure for 10-15 min. The treatment was continued for 2 months and patients were advised to follows a specific diet restriction. Regarding overall effect of both therapies, Moderate improvement was seen in $40 \%$ of patients of group A and $60 \%$ of patients of group B. $60 \%$ of patients were found under Mild improvement in group A and $40 \%$ of patients in group-B. Complete remission was not seen in any patient of both groups.

Bhagyesha K. (2011) ${ }^{[\mathrm{xiv}]}$ :-

The present double blind placebo control clinical study designed on 4 groups randomly in 40 patients (10 each) to assess the efficacy of real drugs (Ankolakadi capsule and lepa) and level of impact of placebo on Shwitra which is considered to be influenced by the psychosocial factors. Each group consisting of 10 patients were treated with both abhyantara and bahyaprayoga. Internal Yogas are in the form of capsules are advised in 500mg, 6 capsules in 3 divided doses per day. Churna is advised to apply over lesion with warm water and exposure to sunlight for 30 min. Group (Zx) treated with internal Ankolakadi yoga and Bahya prayoga with placebo. Group (Tx) treated for internal placebo and Bahya prayoga with Ankolakadi lepa. Group (Xx) treated with internal Ankolakadi yoga and Bahya prayoga with Ankolakadi lepa. Group (Ox) treated with internal Placebo and Bahya prayoga with placebo. Effective results showed in medicine groups are (Group Tx and Group Xx). All the groups are responded equally for Hamilton anxiety scale, all group shows significant results.

Patel N. L. (2013) ${ }^{[\mathrm{xv}]}$ :-

In this study total 30 patients of Shwitra were registered and randomly divided in two groups by Simple Random Sampling method (Coin toss method). Group A: Virechana group - 15 Patients of Shwitra were treated with classical Trivritadi yoga Virechana Karma followed by internally Dhatryadi Kwatha for 6 weeks and externally Manahshiladi lepa up to the blister formation or max. 2 months. Classical Virechana Karma includes Dipana, Pachana, Snehapana, Abhyanga \& Svedana, administration of Samshodhana Kalpa and Samsarjana Krama. Group B: Shamana group - 15 patients of Shwitra were treated with Dhatryadi Kwatha internally for 6 weeks along with Manahshiladi lepa up to the blister formation or max. 2 months for local application. The result of both therapies were statistically highly significant with their Pitta reducing effect but the results of the Virechana as a Shodhana therapy are better compare to those obtained in Shamana Drug. It emphasizes the importance of Shodhana in Shwitra (Vitiligo).

\section{Pandurang I.P. (2014) $)^{[\mathrm{xvi}]}$ :-}

30 patients having clinical features of Shwitra (Vitiligo) willingly participated in study were randomly divided in two groups from S D M Ayurveda Hospital, Hassan. Out of a total 30 patients taken for the study, six dropped out in middle and did not continue treatment. The left out 24 patients constituted of 11 in placebo and 13 in treated group. Trikatu Churna 1gram thrice daily with Ushnodaka was administered before food for two days prior to Snehapana for Pachana and Agnideepana. Starting from $30 \mathrm{ml}$ per day Moorchita Goghruta was administered for Snehana by increasing it by another $30 \mathrm{ml}$ per day until the appearance of Kosta Snigdha Lakshanas. Abhyanga was then carried out with Moorchita Tilataila daily followed by Sarvanga Swedana (for five minutes) for three days. 20 gram of Aragvadha Phala Majja was then administered with warm Ksheera on third day after Abhyanga and Swedana, in the morning in empty stomach. 1 gram of Khadirasara was mixed with $100 \mathrm{ml}$ of drinking water and was advised for drinking by both groups of patients. After this, patients of both the groups were advised to apply the placebo daily in the morning on the Vitiligo patches with Ewe's milk and were advised to expose the patches to the sunlight for 15 minutes and trial drugs given to them daily once for two months. After treatment, there was significantly increased number of black spots in the lesion on an average by $31 \%$ and improved colour of patches towards the normal on an average by $38.33 \%$ while there was $19 \%$ reduction in size of patches in treated group patient. Overall the placebo had no effect on any of the criteria taken in the present study. Overall trial drug is found to be more effective in altering the colour of the patch.

Jadav H.R. (2014) ${ }^{[\mathrm{xvii}]}$ :-

Total 55 patients of Shwitra were registered and randomly divided in two groups with the help of computer generated random selection method viz. Group A- Apamarga Kshara Yoga Lepa (Apamarga Kshara and 
Manahshila with in Gaumutra) and Group B- Apamarga Kshara Yoga Ointment (prepared by same as Lepa but added Siktha Taila as a base for Ointment was used) in Quantity sufficient for local application in both the groups and Rasayana churna $3 \mathrm{gm}$ with Madhu and Ghrita. The study was cleared by the institutional ethics committee (PGT/7-A/2012-2013/1964/23 dated 21/09/2012). The trial was register in Clinical Trial Registry of India (CTRI) (CTRI/2012/11/003157 dated 30/11/2012). Clinically Apamarga Kshara Yoga Lepa (Group A) exhibited significant result in comparison to Apamarga Kshara Yoga ointment (Group B).Comparison in between the groups is insignificant. So both drugs are effective in treating Shwitra (Vitiligo).No any another side effects have been reported by the patients during the study or in follow up time.

Raghwani H.U. (2014) ${ }^{[x v i i i]}$ :-

In this study total 92 patients of Shwitra were registered and randomly divided in three groups by lottery Random Sampling method. Group A, Group B \& Group C. Group A- Classical Vamana Karma was given. Group BClassical Virechana Karma was given. In both of these groups; oral administration of Darvigomootra Ghanavati $6 \mathrm{gm} /$ day with the Apamargkshara Lepa for duration of 8 weeks were given after Shodhana.

Group C- Oral administration of Darvigomootra Ghanavati 6gm/day with the Apamarghkshara Lepa for duration of 8 weeks.

DarviGomootra Ghanavati: Prepared with Darvi (Berberis aristata) and Gomootra (Cow Urine) by the classical method of Ghana Kriya.

Apamargkshara Lepa: Prepared with Apamargkshara and Gomootra.

Study was registered in Clinical Trial Registry of India with no. CTRI/2014/09/005004. The result of both Shodhana therapies were statistically highly significant though no significant difference was found between Vamana \& Virechana therapy, hence Virechana Karma can better management of Shwitra. Only Virechana group provided marked improvement and it is easy to perform with less complication and it emphasizes the importance of Shodhana in Shwitra.

\section{Shingadiya R. (2015) ${ }^{[\mathrm{ix}]}$ :-}

In this study, total 60 patients of Shwitra were registered, 52 completed and randomly divided in two groups, Group A and Group B with the help of computer generated random selection method viz., Group A $(n=24)$ : Treated with Savarnakara Lepa ${ }^{[\mathrm{xx}]}$ prepared by using equal quantity of Ashuddha Haratala and Bakuchi with in Gaumutra (cow's urine).Group B (n=28): Treated with Savarnakara Ointment prepared by same ingredients as Lepa but added Siktha Taila as a base for Ointment was used. Kanakabindvarishta was administered internally in both groups.Dose of External Drug: Quantity sufficient for local application in both the groups and for Internal Drug: Kanakabindvarishta ${ }^{x x i}-20 \mathrm{ml}$ twice a day with equal quantity of water.The study was Randomized open trial study cleared by the institutional ethics committee (PGT/7-A/Ethics/2013-2014/1767). The trial was register in Clinical Trial Registry of India (CTRI) (CTRI/ 2013/12/004232). Clinically Savarnakara Lepa (Group A) and Savarnakara ointment (Group B) are equally effective in Cardinal Symptoms (Colour, Number, Area and Size of patches) and associate Symptoms (Mandalottapatti, Rukshata, Saparidaha, Bahalatva and Kandu) of Shwitra (Vitiligo). Due to having very short duration of treatment ( 2 months) and smaller sample size (52); no patients reported in complete cure group.

\section{Discussion:-}

The skin is the largest and most visual organ of the human body. Shwitra is most blemishing disease compared to other dermatological problems. The condition which has white colour vitiated in skin is called 'Shwitra'. Acharya Charaka has listed the Shwitra under the Rakta Pradoshaja Vikara ${ }^{[x x i i]}$. Ayurveda emphasized diet as an important etiological factor. Because samyak yojita Ahara leads to indriya prasadana and varna prasadana. But Asamyak yojita Ahara leads to several diseases. Hence Twak is also influenced by Aharaja Nidana, recent studies have been shown significant role of food as possible etiological factor in cause the disease. Viruddha Ahara i.e., incompatible diet is mentioned as the prime causative factor of Kushta in general and Shwitra in particular. These incompatible foods are responsible for the formation of Ama (endogenous antigen source). Ama may interfere with absorption nutrients which accepted as one of the etiological factor for Vitiligo as prolonged consumption of diet poor in protein and cuprominerals was thought to be contributory factor for Vitiligo ${ }^{\text {[xiiii] }}$. Charaka also opines that the papakarma, guruninda, unlawful acts, are also causes Shwitra. There is no logic which can be put forth regarding involvement of these Nidana. 
Vitiligo is a condition in which only active (melanin-producing) melanocytes destroyed and the inactive melanocytes in the outer root sheath (ORS) of normal hair follicles are preserved and serve as the only source for the re pigmentation Recovery of Vitiligo is initiated by the proliferation of these inactive melanocytes, followed by the upward migration of inactive melanocytes to the nearby epidermis to form peri-follicular pigment islands ${ }^{\text {[xiv }]}$. The Bakuchi and Kakodumbara contain active principle psoralens and reaches at the inactive melanocytes getting concentrated into the cytoplasm which then increases the photosensitivity of the inactive melanocytes. Further this helps in synthesis of melanin pigment which is deficient in Vitiligo. Exposure to sunlight was advised to follow after the local application early in the mornings to patients because both the Psoralens and sunlight stimulate tyrosinase enzyme which is responsible for the melanin synthesis. The sunlight being radiant energy it may potentiates the action of external application. Thus may results in perfect permeability of drug through epidermis and which result in perfect stimulation of the melanocytes for their normal function melanogenesis. This increases the production of facultative melanin.

Acharaya Charaka has mentioned Shodhana therapy especially as a line of treatment of in Shwitra ${ }^{[\mathrm{xxv}]}$. According to Harita Samhita the specific line of treatment Virechana is given ${ }^{\text {xxvi }}$.According Charakacharya Svitra has been considered under one of the Rakta Pradoshaja Vikara. So following line of treatment can be taken for consideration

${ }^{[x x v i i]}$.Diseases having blood as causative factor line of treatment is one pacifying Rakta and Pitta. Also, Virechana, Upavasa and Rakta mokshana can be given ${ }^{\text {[xxviii] }}$.

For any disease to manifest Dosha-Dushya Samurchana is must, that is nothing but what we say as Samprapti. This having maximum attention as Samprapti vighatan itself is the basic thought of treatment in any disease. So to understand probable mode of action of yoga we have to think how the quality of individual drugs of the yoga will act against the Samprapti ghatakas. Shwitra is a Tridoshaj Vyadhi. The ingredients of various internal yogas act over tridoshas and pacify them. External application i.e. lepa, ointments etc. having ushana, teekshana and srotoshodaka properties ${ }^{[\mathrm{xxix}]}$.The veerya of them reaches the siramukha of swedavaha srotas and reach the deeper layer twaka and it act locally to relive the sanga. By this the samapurana of Bhrajaka pitta takes place and hence normal function is noticed.

\section{Conclusion:-}

Above various studies on Shwitra conclude that better significant results can be achieved by Shodhana therapy (biocleansing) followed by Shamana (palliative) therapy and also with altered preparation of external application made by different medias. Those combine treatments may play major role in the management of Shwitra (Vitiligo).

\section{References:-}

i Shashtri SN,editor, Charaka samhita of Agnivesha, Part 1, Charak samhita Sutrasthana Chapter 30, Verse.26, Reprint Edition,Varanasi: Chaukhambha bharati Academy, 2013; 587p.

ii Shashtri SN,editor, Charaka samhita of Agnivesha, Part 2, Charak samhita Chikitsasthana Chapter 7, Verse.177, Reprint Edition,Varanasi: Chaukhambha bharati Academy, 2013;275p.

iii Siddharth N, editor, API Text book of Medicine, dermatology, $8^{\text {th }}$ Edition, Association Physician of India Mumbai, 1999; 1411, 1412, 1463p.

iv Tripathi B, editor, Astang hridaya of Vaghbhatta, Sutrasthana, Ch. 1, Verse.25, Reprint Edition, Delhi: Chaukhambha Sanskrit Paristhan;2012. p.19

v Shashtri SN,editor, Charaka samhita of Agnivesha, Part 1, Charak samhita Sutrasthana Chapter 15, Verse.22, Reprint Edition,Varanasi: Chaukhambha bharati Academy, 2013;275p.;317p.

vi Shashtri SN,editor, Charaka samhita of Agnivesha, Part 1, Charak samhita Sutrasthana Chapter 16, Verse.20, Reprint Edition,Varanasi: Chaukhambha bharati Academy, 2013;321p.

vii Yvon G, Muriel A, Alain T, Review "A Critical Appraisal of Vitiligo Etiologic theories, Is Melanocyte Loss a Melanocytorrhagy?’Pigment Cell Res, ISSN 0893-5785, 16: 2003; 322-332p.

viii Tiwari SK, Rangarao C, Kethamakka SP,Evaluation of the efficacy of Dhatrayadi Yoga (Internal) and Avalgujadi lepa (external) along with and without sodhana (Vamana) in Shvitra (with special reference to Vitiligo), PG Dissertation submitted to D.G. Melmalagi Ayurvedic Medical College, Gadag, 2001

${ }^{\text {ix }}$ Venkaraddiyavar B.H., Varadacharyulu V, Shettar R.V., Evaluation Of The Efficacy Of Kakodumbaradighanavati (Internal) And Ayorajadilepa (External) In The Management Of Shvitra, PG Dissertation submitted to D.G. Melmalagi Ayurvedic Medical College, Gadag, 2006 
${ }^{x}$ Manisha Goyal, Prajapati P.K., A Comparative Pharmaceutico Clinical Study Of Karpanpatru Taila Prepared With Different Medias And Its Effect On Shvitra (Vitiligo), PG Dissertation submitted to IPGT \&RA, Gujarat Ayurved University, Jamnagar, 2008

xi Jayawardana C.T. Comparative Study Of Bakuchi Haritala Yoga And Bakuchi Thailaya With Special Reference To Shvitra (Vitiligo), Dissertation submitted to Institute Of Indigenous Medicine, University Of Colombo, Shrilanka,2009

xii Mittalakod K.S., Danappagoudar G.N., Mitti J.G., Physico Chemical analysis of Shvitrari Rasa and Lepa, their Clinical Efficacy on Shvitra, PG Dissertation submitted to D.G. Melmalagi ayurvedic medical college, Gadag, 2009

xiii Deepika Tyagi, Pandya D, Joshi N.P., A comparative Study of Khadiradi yoga and Khadiradi taila with Kakodumbar ghanvati \& Kakodumbar Taila in the management of Shvitra, PG Dissertation submitted to Gujarat Ayurved University, Jamnagar, 2010

xiv Bhagyesha K, Babu SS, Mulki Patil B.M., Evaluation Of Effect Of Ankolakadi Yoga In Shvitra With Special Reference To Vitiligo, PG Dissertation submitted to D.G. Melmalagi Ayurvedic Medical College, Gadag, 2011

xv Patel N.L.,.Thakar A.B., A comparative clinical study between Dhatryadi Kwatha and Manhshiladi Lepa along with and without Trivritadi Yoga Virechana administrated in the management of Shvitra w.s.r. to Vitiligo PG Dissertation submitted to Gujarat Ayurved University, Jamnagar, 2013

xvi Pandurang I.P., Effect Of Certain Ayurvedic Drugs On Vitiligo (Shvitra) In Children, IAMJ: Volume 2, Issue 5, September- October ;2014

xvii Jadav H.R., Prajapati P.K., Galib, Shukla V.J., Pharmaceutical Standardisation of Two Different Dosage Forms of Apamarga Kshara Yoga and their Clinical Efficacy on Shvitra (Vitiligo), PG Dissertation submitted to Gujarat Ayurved University, Jamnagar, 2014

xviii Raghvani H.U.,Thakar A.B.,A clinico comparative study of vamana \& virechana karma in the management of the shvitra w.s.r. To Vitiligo, PhD Dissertation submitted to Gujarat Ayurved University, Jamnagar, 2014

xix Shingadiya R, Prajapati PK, Shukla VJ, Pharmaceutical standardization of two different dosage forms of Savarnakara yoga and its efficacy on Shvitra (Vitiligo), PG Dissertation submitted to Gujarat Ayurved University, Jamnagar, 2015

xx Tripathi B, editor, Astang hridaya of Vaghbhatta ,Chikitsasthana, Ch. 20, Ver.13, Reprint Edition, Delhi: Chaukhambha Sanskrit Paristhan;2012;799p.

xxi Shashtri SN,editor, Charaka samhita of Agnivesha, Part 1, Charak samhita Chikitsasthana Chapter 7, Verse.171-172, Reprint Edition,Varanasi: Chaukhambha bharati Academy, 2013;216p.

xxii Shashtri SN,editor, Charaka samhita of Agnivesha, Part 1, Charak samhita Sutrasthana Chapter 26, Verse.103, Reprint Edition,Varanasi: Chaukhambha bharati Academy, 2013; 523p.

xxiii Valia R.G., editor, Text book and atlas of dermatology ,Vol 1, $1^{\text {st }}$ Eedition, Chapter 22, Bombay: Bhalani publishing house;518p.

xxiv Hann SK, Norland JJ, Vitiligo, $1^{\text {st }}$ Edition, Chapter 8, Bangalore: Panther publishers' private limited, 2000; $112 \mathrm{p}$.

xxv Shashtri SN,editor, Charaka samhita of Agnivesha, Part 2, Charak samhita Chikitsasthana Chapter 7, Verse.162, Reprint Edition,Varanasi: Chaukhambha bharati Academy, 2013; 272p.

xxvi Tripathi H.P., editor, Harita samhita of Harita, Tritiya Sthana, Chapter 39, Verse. 50, 51, Reprint edition, Varanasi: Chaukhambha Krishnadas acadamy, 2009.

xxvii Shashtri SN,editor, Charaka samhita of Agnivesha, Part 1, Charak samhita Sutrasthana Chapter 28, Verse.13, Reprint Edition,Varanasi: Chaukhambha bharati Academy, 2013; 571,572p.

xxviii Shashtri SN,editor, Charaka samhita of Agnivesha, Part 1, Charak samhita Sutrasthana Chapter 24, Verse.18, Reprint Edition,Varanasi: Chaukhambha bharati Academy, 2013; 445p.

${ }^{\text {xxix }}$ Sharma S, Shastri HD, Shastri KN, Editors, Ras tarngini, Motilal banarasidas publishers, Delhi, 14-71p. 